\title{
Cultivation of Pleurotus sajor-caju on banana stalk and Bahia grass based substrates
}

\author{
Félix G de Siqueira'; Emerson T Martos²; Romildo da Silva²; Eustáquio S Dias ${ }^{2}$ \\ ${ }^{1}$ UnB-Depto. Biologia Celular, Lab. Enzimologia, 70910-900 Brasília-DF, ogatofelix@gmail.com; ${ }^{2}$ UFLA-Depto. Biologia, C. Postal, \\ 3037,37200-000 Lavras-MG, etmartos@gmail.com; romsilva@ufla.br; esdias@ufla.br
}

\begin{abstract}
Banana stalks and Bahia grass were utilized as basic starting materials for the production of the mushroom Pleurotus sajor-caju. Banana stalks were combined with other waste or supplement products (wheat bran, coast-cross hay, bean straw and cotton textile mill) to obtain different nitrogen concentrations. Since Bahia grass is relatively rich in protein, it was combined with other substrates (banana stalk, coast-cross hay and bean straw) to maintain a substrate nitrogen concentration of about $1.5 \%$. Banana stalks and Bahia grass were both more efficient in the production of the mushroom $P$. sajor-caju when utilized without the addition of other substrates, with biological efficiencies of $74.4 \%$ and $74.12 \%$, respectively. When combined with other substrates or grasses, there was a drop in biological efficiency, independent of the concentration of nitrogen. Furthermore, the addition of protein-rich waste to banana stalks resulted in a decrease or absence of fructification, which indicates that high concentrations of nitrogen in the cultivation substrate may hinder the cultivation of this mushroom. On the other hand, results reveal that the ideal concentration of nitrogen may depend on other physicochemical factors and these factors may determine the success in cultivating $P$. sajor-caju. Therefore, we conclude that $P$. sajor-caju may be cultivated on banana stalk and Bahia grass as pure substrates, not being necessary their supplementation or combine them with another substrates.
\end{abstract}

Keywords: Mushroom cultivation, agro-industrial waste, axenic cultivation, nitrogen concentration.

\section{RESUMO}

Cultivo de Pleurotus sajor-caju em substratos a base de grama batatais e engaço de bananeira

O engaço de bananeira e a grama batatais foram utilizados como matérias-primas básicas para a produção do substrato de cultivo do cogumelo Pleurotus sajor-caju. O engaço de bananeira foi combinado com outros resíduos (farelo de trigo, capim "Coast-cross", palha de feijão e resíduo de lixadeira de algodão), com o objetivo de se obter substratos com diferentes concentrações de nitrogênio. Como a grama batatais é relativamente rica em proteína, a mesma foi combinada com outros resíduos (engaço de bananeira, capim "Coast-cross" e palha de feijão), de forma a manter a concentração de nitrogênio em torno de $1,5 \%$ no substrato. O engaço de bananeira e a grama batatais foram mais eficientes na produção do cogumelo $P$. sajor-caju quando utilizados puros, com uma eficiência biológica de 74,4 e 74,12\%. Quando foram combinados com outros resíduos ou gramíneas, houve uma queda na eficiência biológica, independente da concentração de nitrogênio. Entretanto, para o engaço de bananeira, a adição de resíduos mais protéicos resultou em queda mais acentuada ou até mesmo na ausência de frutificação, indicando que concentrações mais elevadas de nitrogênio no substrato de cultivo podem prejudicar o cultivo deste cogumelo. Por outro lado, os resultados indicaram também que a concentração ideal de nitrogênio depende de outros fatores físico-químicos do substrato de cultivo, os quais podem estar associados na determinação da produtividade do cogumelo P. sajor-caju. Portanto, pode-se concluir que $P$. sajor-caju pode ser cultivado utilizando engaço de bananeira e grama batatais como substratos puros, não sendo necessária a sua suplementação ou combinação com outros substratos.

Palavras-chave: Cultivo de cogumelos, resíduos agro-industriais, cultivo axênico, concentração de nitrogênio.

(Recebido para publicação em 2 de agosto de 2010; aceito em 5 de maio de 2011)

(Received on August 2, 2010; accepted on May 5, 2011)

$\mathrm{O}$ yster mushroom is the third most cultivated edible mushroom in the world (Royse, 2003), probably including Brazil. There isn't official statistics about mushroom production in Brazil, but different Pleurotus species have been cultivated and $P$. ostreatus is the most important oyster mushroom cultivated in this country.

The mushroom Pleurotus sajorcaju has a promising future in the tropical and subtropical countries, because its cultivation requires simple, and relatively inexpensive cultivation techniques (Chang \& Miles, 2004). Therefore, these interesting attributes make it an excellent option for cultivation in Brazil, particularly in regions with warmer climates (Dias, 2010). It's simple cultivation technique allows that agro wastes may be used to produce a highly nutritious food and of high commercial value (Mane et al., 2007).

Oyster mushrooms contain various types of vitamins and amino acids, high content of fiber and low fat content (Chang \& Miles, 2004). Mushrooms are also considered a good source of protein, considering protein content of dry mushroom, however, it is important to emphasize that the protein content of fresh mushroom is hardly higher than 4\% (Silva et al., 2007; Bernardi et al., 2009). On the other hand, oyster mushrooms have medicinal properties which make it a functional food (Gunde-Cimerman \& Cimerman, 1995; Pramanik et al., 2005; Alarcón \& Aguila, 2006; Jedinak 
\& Silva, 2008).

Pleurotus cultivation in Brazil was established using sugarcane bagasse as basic mushroom substrate (Maziero et al., 1992). However, this agro waste is not abundant in all regions and bagasse is often utilized as fuel in manufacturing plants, which limits its availability. Thus, the search for an alternative agroindustrial substrate is very important to allow cultivation of this mushroom in regions where bagasse is not available. Dias et al. (2003) evaluated different agro-industrial substrates, both pure and enriched with wheat bran, and demonstrated that bean straw alone and corn straw enriched with wheat bran facilitated the best $P$. sajor-caju mushroom production. However, it is important to evaluate other substrates or raw materials, so that mushroom growers may have alternatives to produce a suitable mushroom cultivation substrate.

Sturion (1994) proposed using banana leaves for the cultivation of Pleurotus spp. oyster mushrooms because of the vast availability of this waste product in the Southeast part of Brazil. However, banana leaves and pseudostems from harvested plants are chopped and left in the field as mulch, following common local practice, allowing nutrient recycling, humidity maintenance, weed control and prevention of earth erosion. Additionally, the pseudostems, stalks and leaves of the banana plant are used for hand-made products like ropes, rugs, hats, baskets and paper (Chertman, 2007). The banana stalk, however, is not consistently used, and after the process of separating the banana bunches, this material is often disposed of inappropriately, generating serious environmental and sanitary problems (Soffner, 2001). Thus, the utilization of banana stalks in biotechnological procedures, such as enzyme production and mushroom cultivation, provides an important alternative use for this waste.

Besides allowing for the utilization of a variety of waste products, a plan for mushroom cultivation must include the possibility of utilizing grasses that are easy to grow or obtain. As such, if there is lack of the commonly utilized waste source, it would be possible to use grasses instead of waste to generate a cultivation substrate (Bernardi et al., 2009; Donini et al., 2009).

The grass Paspalum notatum Fluegge (popularly known as Bahia grass or "batatais") is a common, rustic grass that resists drought, disease and trampling (Mislevy, 1985; Monteiro, 1986). This grass can be used to control erosion, as it grows reticular roots that filter water very well. In addition to this important function, it can also be used as animal feed and is commonly used as grass in public parks, landscaped areas and football fields (Mislevy, 1985; Monteiro, 1986). Due to its many advantages, Bahia grass is an excellent option for a raw material for mushroom cultivation.

The aim of this work was to evaluate the potential for utilization of banana stalks and Bahia grass as basic raw materials (in association with other substances) for the cultivation of the $P$. sajor-caju mushroom.

\section{MATERIAL AND METHODS}

Spawn preparation - To produce spawn of $P$. sajor-caju, whole grain rice (husk enclosed) was utilized $(9.0 \mathrm{~kg})$ after being pre-cooked for approximately 30 minutes. The precooked rice was enriched with a mixture of wheat bran (1 kg), gypsum (200 g), limestone (200 g) and water (1 L), which had been autoclaved for 30 minutes at $121^{\circ} \mathrm{C}$. After cooking the whole grain rice, the excess water was drained and added to the autoclaved mixture. The material was transferred into flasks (400 g/flask), which were autoclaved at $121^{\circ} \mathrm{C}$ for two cycles of 1 hour each, following a 24-hour interval. The flasks were left to cool at room temperature and inoculated with mycelia of $P$. sajor-caju taken from 7-day old cultures grown on PDA medium (potato-dextrose agar). The flasks were incubated at room temperature for 20 days.

Substrate preparation, spawning and spawn run - Bahia grass $(P$. notatum) was sun-dried for two days after harvest. Banana stalks (Musa cavendishii, "Prata" variety), Coast- cross hay (Cynidon dactylon) and bean straw (Phaseolus vulgaris), after drying for two days, were chopped into small pieces to obtain a more homogeneous mixture for the substrate preparation. Cotton textile mill waste (Gossypium hirsutum), which originates from the fabric mills in the region of Itaúna (State of Minas Gerais, Brazil) and wheat bran were not subjected to any dehydration or grinding treatment because they were already ground and dried. All materials for chemical analysis were first dried at $65^{\circ} \mathrm{C}$ for 48 hours before being weighed.

Substrate formulations were determined according to the nitrogen concentration of each raw material to select the substrates with nitrogen contents from $1.0 \%$ to $1.6 \%$. Since Bahia grass contains high nitrogen levels (Oliveira et al., 2005), the nitrogen concentrations of substrates containing Bahia grass were maintained at $1.4 \%$ to $1.5 \%$ nitrogen. Total nitrogen ( $\mathrm{N}$-total) content of the raw materials and the formulated substrates were determined using the micro-Kjeldahl method, and the acid detergent fiber (ADF) and neutral detergent fiber (NDF) contents, defined according to the method of van Soest (1994), were determined as described by Silva \& Queiroz (2002). The ADF-NDF value corresponds to the level of hemicellulose, and the ADF value corresponds to the sum of cellulose and lignin. The determination of cellulose and lignin content was done via the permanganate $\left(\mathrm{KMnO}_{4}\right)$ method (Queiroz, 2002).

For experiment 1, banana stalk was combined with different raw materials in the following combinations: $\mathrm{E}_{1} \mathrm{~T}_{1}=$ $100 \%$ banana stalk; $\mathrm{E}_{1} \mathrm{~T}_{2}=$ stalk $(90 \%)$ + wheat bran (10\%); $\mathrm{E}_{1} \mathrm{~T}_{3}=\operatorname{stalk}(50 \%)$ + "coast-cross" hay (50\%); $\mathrm{E}_{1} \mathrm{~T}_{4}=$ stalk $(80 \%)+$ bean straw $(20 \%)$ and $\mathrm{E}_{1} \mathrm{~T}_{5}=$ stalk $(80 \%)+$ cotton textile mill waste $(20 \%)$. For experiment 2, Bahia grass was combined with different agricultural wastes in the following combinations: $\mathrm{E}_{2} \mathrm{~T}_{1}=100 \%$ Bahia grass; $\mathrm{E}_{2} \mathrm{~T}_{2}=$ Bahia grass $(40 \%)+$ banana stalk $(60 \%) ; \mathrm{E}_{2} \mathrm{~T}_{3}$ $=$ Bahia grass $(20 \%)+$ "coast-cross" hay $(20 \%)+$ banana stalk $(60 \%)$ and $\mathrm{E}_{2} \mathrm{~T}_{4}=$ Bahia grass $(20 \%)+$ bean straw $(20 \%)$ + banana stalk $(60 \%)$.

The ingredients were properly mixed 
and tap water was added to reach an approximate humidity level of $65 \%$. The humidity was determined in relation to the components dry weight. Following preparation of each substrate, a sample was collected to determine the drymaterial content for calculation of the biological efficiency (BE) of mushroom production. The substrates were filled into $20 \times 40 \mathrm{~cm}$ polypropylene bags ( $1 \mathrm{~kg} / \mathrm{bag})$, which were protected with filter paper fixed to a hard plastic ring (PVC), in order to allow fungal gaseous exchange and to avoid contamination by other competing fungi. The bags were autoclaved at $121^{\circ} \mathrm{C}$ for two hours, allowed to cool at room temperature and each bag was inoculated with $10 \mathrm{~g}$ of spawn under laminar flow chamber. The steps of each experiment were carried out in a completely randomized design, with 10 replicates, and spawn run was carried out in a dark room until complete colonization of all substrates.

Fruiting induction and mushroom production - After colonization of all the substrates, the plastic bags were perforated and then transferred to the mushroom house without temperature control. The temperature ranged between $16^{\circ} \mathrm{C}$ (at night) and $30^{\circ} \mathrm{C}$ (during the day), and the relative humidity was controlled between $80 \%$ and $90 \%$ with a nebulizer system. The mushroom house temperature was monitored by a maximum and minimum thermometer. The fruiting bodies were harvested in three flushes after one month of growth, and the mushrooms were weighed to determine their productivity ( $g$ of fresh mushroom/g of humid substrate $\mathrm{x} 100$ ) and BE ( $g$ of fresh mushroom/g of dry substrate $\mathrm{x} 100$ ). Treatment means were separated using Scott-Knott test at 5\% level.

\section{RESULTS AND DISCUSSION}

The total nitrogen levels of all substrates were determined in each experiment. These values varied from $1.1 \%$ to $1.6 \%$ in experiment 1 (Table 1 ) and from $1.4 \%$ to $1.5 \%$ in experiment 2 (Table 2). These values were predetermined from the dry material at the time each substrate was first prepared. Initial nitrogen levels were

Table 1. Initial nitrogen levels and lignocellulose composition of banana stalk based substrates for $P$. sajor-caju cultivation (níveis iniciais de nitrogênio e composição dos substratos à base de engaço de bananeira no cultivo de P. sajor-caju). Lavras, UFLA, 2007.

\begin{tabular}{lcccc}
\hline Substrates & $\begin{array}{c}\text { N-Total } \\
(\%)\end{array}$ & $\begin{array}{c}\text { Cellulose } \\
(\mathbf{\%})\end{array}$ & $\begin{array}{c}\text { Hemicellulose } \\
(\mathbf{\%})\end{array}$ & $\begin{array}{c}\text { Lignin } \\
(\mathbf{\%})\end{array}$ \\
\hline $\mathrm{T}_{1}-$ Stalk & 1.2 & 26.3 & 12.4 & 18.4 \\
$\mathrm{~T}_{2}-$ Stalk + wheat bran & 1.6 & 34.1 & 16.0 & 17.4 \\
$\mathrm{~T}_{3}-$ Stalk + h. "coast-cross" & 1.1 & 31.1 & 28.0 & 17.1 \\
$\mathrm{~T}_{4}-$ Stalk + bean straw & 1.4 & 26.6 & 15.5 & 18.5 \\
$\mathrm{~T}_{5}-$ Stalk + cotton substrate & 1.2 & 20.9 & 10.4 & 16.2 \\
\hline
\end{tabular}

predicted from substrate set-up, so that the initial concentration remained above $1.0 \%$ and less than $1.6 \%$ (Tables 1 and 2 ), since it has been shown in previous studies that the mycelial growth of $P$. sajor-caju does not occur in substrates with nitrogen levels above $1.7 \%$ (Silva et al., 2007). Tables 1 and 2 also show the cellulose, hemicellulose and lignin contents for each substrate tested.

In experiments 1 and 2 , the various treatment conditions showed colonization times that varied from 24 to 35 days (Tables 3 and 4). In the experiment with banana stalk based substrates, longer spawn run time was correlated with lower productivity or no mushroom production. On the other hand, in the second experiment, the longest spawn run time was obtained on pure Bahia grass substrate, but the highest mushroom production was also obtained for this substrate, showing that a long colonization time is not always a sign of a poor mushroom production. According to the results obtained by Donini et al. (2006), the supplementation with soybean meal, wheat, rice and maize did not favor increasing the rate of mycelium growth of different strains of $P$. ostreatus, grown on the elephant grass substrate.

Mandeel et al. (2005) reported that spawn run of $P$. sajor-caju was different when grown in various substrates, varying from 2 to 4 weeks. According to Obodai et al. (2003), spawn run of Pleurotus ostreatus in substrates such as rice stalk, banana leaf, corn stem and rice fiber varied between 15 and 34 days, and the rice stalk had the best colonization time. The same authors also showed that the time of appearance of the first primordia after induction of fruiting varied between 4 and 6 days in these substrates, and the harvest of the majority of the mushrooms occurred during the first three harvests within 8 weeks of cultivation.

In our study, the first flush of mushrooms occurred between 3 and 5 days after fruiting induction for all treatments in both experiments. During a 30-day interval, three harvests were performed, meaning three flushes of mushrooms were used to evaluate the productivity and biological efficiency of each substrate tested. Cultivation was extended for a period of 55 days, with up to five harvests, but more than $50 \%$ of the mushrooms were collected during the first two flushes.

The productivity and biological efficiency results show that banana stalk and Bahia grass are more efficient for cultivation of P. sajor-caju when utilized without supplementation (Tables 3 and 4). These results are very interesting because they point to a very simple strategy for substrate preparation for cultivation of this mushroom. The biological efficiency reached was approximately $74 \%$ for both pure substrates. In the case of P. ostreatus, it is possible to reach a biological efficiency greater than $100 \%$, as described by Contreras et al. (2004) and Mandeel et al. (2005). However, these values can vary substantially, depending on the type of substrate and cultivation strategy. In the case of P. sajor-caju, results can also be highly variable, but the biological efficiency is usually less than $100 \%$. Moda et al. (2005), using washed and supplemented sugarcane bagasse, obtained a maximum biological efficiency of $30.03 \%$ with $P$. sajorcaju, while Dias et al. (2003) obtained 
Table 2. Total nitrogen levels (N-total) and lignocellulose composition of Bahia grass based on substrates for $P$. sajor-caju cultivation (níveis de nitrogênio total (N-total) e composição dos substratos à base de grama batatais no cultivo de P. sajor-caju). Lavras, UFLA, 2007.

\begin{tabular}{lcccc}
\hline Substrates & $\begin{array}{c}\text { N-Total } \\
(\mathbf{\%})\end{array}$ & $\begin{array}{c}\text { Cellulose } \\
\mathbf{( \% )}\end{array}$ & $\begin{array}{c}\text { Hemicellulose } \\
\mathbf{( \% )}\end{array}$ & $\begin{array}{c}\text { Lignin } \\
(\mathbf{\%})\end{array}$ \\
\hline $\mathrm{T}_{1}$-Bahia grass & 1.4 & 32.74 & 25.65 & 17.35 \\
$\mathrm{~T}_{2}$ - Bahia grass + banana stalk & 1.4 & 27.21 & 19.90 & 18.82 \\
$\mathrm{~T}_{3}$ - Bahia grass + h. "coast-cross" + banana stalk & 1.5 & 28.08 & 16.23 & 18.02 \\
$\mathrm{~T}_{4}$-Bahia grass + bean straw + banana stalk & 1.5 & 23.92 & 16.30 & 20.25 \\
\hline
\end{tabular}

Averages followed by the same letter in a given column are not statistically different from each other based on the Scott-Knott test at a $5 \%$ probability level (médias seguidas pela mesma letra em uma coluna não são estatisticamente diferentes entre si, baseados no teste de Scott-Knott ao nível de 5\% de probabilidade); $*$ Productivity $=[(\mathrm{g}$ of fresh mushroom $/ \mathrm{g}$ of humid substrate $) \times 100]$ (produtividade $=[(\mathrm{g}$ de cogumelos frescos/g de substrato úmido $) \times 100]) ; * *$ Biological Efficiency $=[(\mathrm{g}$ of fresh mushroom/g of dry substrate $) \times 100](* *$ eficiência biológica $=[(\mathrm{g}$ de cogumelos frescos/g de substrato seco $) \times 100])$.

Table 3. Productivity and biological efficiency of $P$. sajor-caju cultivated on banana stalk based substrates (produtividade e eficiência biológica de $P$. sajor-caju nos substratos à base de engaço de bananeira). Lavras, UFLA, 2007.

\begin{tabular}{lccc}
\hline Substrates & $\begin{array}{c}\text { Colonization } \\
\text { (days) }\end{array}$ & $\begin{array}{c}\text { Productivity } \\
(\%) *\end{array}$ & $\begin{array}{c}\text { Biological efficiency } \\
(\mathbf{\%}) * *\end{array}$ \\
\hline $\mathrm{T}_{1}-$ Stalk & 26 & $15.6 \mathrm{a}$ & $74.4 \mathrm{a}$ \\
$\mathrm{T}_{2}-$ Stalk + wheat bran & 35 & $0.0 \mathrm{e}$ & $0.0 \mathrm{e}$ \\
$\mathrm{T}_{3}-$ Stalk + h. "coast-cross" & 28 & $13.4 \mathrm{c}$ & $51.5 \mathrm{c}$ \\
$\mathrm{T}_{4}-$ Stalk + bean straw & 32 & $3.9 \mathrm{~d}$ & $17.5 \mathrm{~d}$ \\
$\mathrm{~T}_{5}-$ Stalk + cotton substrate & 24 & $14.5 \mathrm{~b}$ & $60.4 \mathrm{~b}$ \\
\hline
\end{tabular}

a biological efficiency of $85.7 \%$ using bean straw as pure substrate in an axenic cultivation system.

Biological efficiency is a good standard of comparison for evaluating the efficiency of substrate conversion in mushrooms. However, for mushroom growers, the most practical parameter is productivity, so it must also be considered. In general, a good productivity index starts with values greater than $10 \%$, when considering the weight of fresh mushrooms in relation to wet compost. In this study, the mushroom productivity was $15.6 \%$ and $22.7 \%$ for pure banana stalk and pure Bahia grass substrates, respectively, which can be considered good results (Tables 3 and 4). On the other hand, when the banana stalk was used, a faster spawn run was observed (26 days) than when Bahia grass was used (35 days). The mixture of banana stalk and Bahia grass allowed a reduction of the spawn run period to 27 days, but a significant reduction in productivity was also observed, even though the biological efficiency reduction was not significant. It is also notable that the addition of any substrate or supplement to the banana stalk resulted in a reduction of productivity and biological efficiency and in an increase of the spawn run period, with the exception of treatment 5 (Table 3 ). The addition of wheat bran, besides resulting in a higher spawn run period, resulted in no mushroom production. These results may be associated with the higher nitrogen levels of treatment 2 , as a function of the addition of wheat bran to the banana stalk. Similar results were obtained by Zadrazil \& Brunnert (1980) who reported that excessive nitrogen levels inhibited the fructification of the Pleurotus sp. Silva et al. (2007) reported that substrates with nitrogen concentrations above $1.75 \%$ were not colonized by P. sajor-caju. The authors used urea as a nitrogen-enrichment source; however, they did not test nitrogen concentrations between $1.3 \%$ and $1.75 \%$, leading us to wonder whether the ideal concentration lies between these two values.

The production results for banana stalk based substrates suggest, at first, that nitrogen concentration from $1.4 \%$ inhibits fruiting body formation, since the substrate enriched with bean straw (1.4\% nitrogen) showed a productivity of only $3.9 \%$ and a biological efficiency of $17.5 \%$. Even poorer results were obtained when the substrate was enriched with wheat bran, with a nitrogen concentration of $1.6 \%$, upon which fruiting did not occur, reinforcing the idea that substrates that are very rich in nitrogen are not favorable for the production of $P$. sajor-caju.

On the other hand, all Bahia grass based substrates yielded good results, even though substrates with $1.4 \%$ and $1.5 \%$ nitrogen were used (Table 4 ). A tendency towards better productivity results using substrates with $1.4 \%$, as opposed to $1.5 \%$ nitrogen was observed. The substrate that demonstrated the worst performance was Bahia grass enriched with bean straw and banana stalk, which resulted in $14.76 \%$ of productivity and $54.61 \%$ of biological efficiency. Although these results confirm that nitrogen concentration is an extremely important factor, they also indicate that other factors, such as the combination and quality of different waste products, can be determining factors in mushroom production.

One example of this is the utilization of wheat bran to enrich cultivation substrates, since different kinds of bran are commonly used or recommended for use by previous studies. Dias et al. (2003) observed that the addition of wheat bran gave a positive result when they used corn fiber as a cultivation substrate. However, when bean straw was used, the addition of wheat bran had no effect on the productivity, but it retarded substrate colonization, making 
Table 4. Productivity and biological efficiency of $P$. sajor-caju cultivated on Bahia grass based substrates (produtividade e eficiência biológica de P. sajor-caju cultivado nos substratos à base de grama batatais). Lavras, UFLA, 2007.

\begin{tabular}{lccc}
\hline Substrates & $\begin{array}{c}\text { Spawn run } \\
(\text { days })\end{array}$ & $\begin{array}{c}\text { Productivity } \\
(\mathbf{\%}) *\end{array}$ & $\begin{array}{c}\text { Biological efficiency } \\
(\%)\end{array}$ \\
\hline $\mathrm{T}_{1}-$ Bahia grass & 35 & $22.78 \mathrm{a}$ & $74.12 \mathrm{a}$ \\
$\mathrm{T}_{2}-$ Bahia grass + banana stalk & 27 & $18.54 \mathrm{~b}$ & $67.54 \mathrm{~b}$ \\
$\mathrm{~T}_{3}-$ Bahia grass + coast-cross + banana stalk & 24 & $16.89 \mathrm{~b}$ & $65.01 \mathrm{~b}$ \\
$\mathrm{~T}_{4}-$ Bahia grass + bean straw + banana stalk & 29 & $14.76 \mathrm{c}$ & $54.61 \mathrm{c}$ \\
\hline
\end{tabular}

Averages followed by the same letter in a given column are not statistically different from each other based on the Scott-Knott test at a $5 \%$ probability level (médias seguidas pela mesma letra em uma coluna não são estatisticamente diferentes entre si, baseados no teste de Scott-Knott ao nível de 5\% de probabilidade); $*$ Productivity $=[(\mathrm{g}$ of fresh mushroom $/ \mathrm{g}$ of humid substrate $) \times 100]($ produtividade $=[(\mathrm{g}$ de cogumelos frescos/g de substrato úmido) x 100]); $* *$ Biological Efficiency $=[(\mathrm{g}$ of fresh mushroom/g of dry substrate $) \times 100](* *$ eficiência biológica $=[(\mathrm{g}$ de cogumelos frescos/g de substrato seco $) \times 100])$.

its use, at best, unnecessary. In the present study, the utilization of wheat bran resulted in a negative effect, with complete inhibition of fructification. It is important to highlight that the bean straw enriched with wheat bran had a final nitrogen concentration close to $1.6 \%$, considering the results of the mineral analysis of the substrate used by Dias et al. (2003). These data constitute strong evidence that not only nitrogen concentration, but also other factors present in the waste products combined in the substrate, act together to determine its nutritional quality. Thus, depending on the type of agrowaste and/or supplements combined, it is possible to work with higher final nitrogen concentrations.

Donini et al. (2009) reported higher biological efficiency of Pleurotus ostreatus with elephant grass (Pennisetum purpureum) supplemented with different kinds of bran (wheat, rice and corn bran), except for soy bran, which showed the lowest biological efficiency. Gonçalves et al. (2010) reported the supplementation of cotton textile mill waste with wheat bran and/or in combination with sawdust to cultivate Pleurotus sajor-caju. According to the authors, the best biological efficiency was obtained when cotton waste was supplemented with $20 \%$ wheat bran and no mushroom production was obtained when cotton waste was just combined with sawdust in a $1: 1$ ratio. Therefore, substrate supplementation must be important for substrates having low content of protein, and some supplements may work better than others.

According to Sharma (1995), one of the factors that determine mushroom yield is the proportion of fibrous components present in the substrate and that cellulose, hemicellulose and lignin are important intermediates in the generation of covalent bonds that form new structures. Thomas et al. (1998) related that $P$. sajor-caju productivity is influenced by the amount of cellulose and the cellulose/lignin ratio of the substrates and that these factors are important for the development of basidiocarps. However, it was not possible to draw any correlation between the ratio of cellulose to hemicellulose, or of cellulose to lignin, with $P$. sajor-caju productivity in the various cultivation substrates. Because of this, other nutritional characteristics, such as excess manganese or zinc in the substrate, may act together with excess nitrogen to inhibit $P$. sajor-caju fructification (Kerem \& Hadar, 1995; Dias et al., 2003).

Obtaining better biological efficiency from $P$. sajor-caju in substrates containing only banana stalk or Bahia grass contradicts the common view that a combination of several substrates or grasses is best for obtaining a substrate with a balance of nutrients. Just as has been seen with pure bean straw (Dias et al., 2003), these results confirm that certain agro-wastes have physicochemical traits that are appropriate for Pleurotus cultivation. The possibility of utilizing only one agro-waste or kind of grass is very important because it eliminates the need for supplements, diminishes dependence on the availability of basic materials and makes the process even simpler for the mushroom grower, which may allow for the reduction of material preparation time and production costs.

Therefore, P. sajor-caju may be cultivated in a substrate containing only banana stalk or Bahia grass in an axenic system. It is not necessary to supplement these substrates with wheat bran or to combine these substrates with each other or with other agricultural wastes to successfully cultivate this mushroom.

\section{ACKNOWLEDGEMENTS}

To FAPEMIG/CAPES/CNPq for their financial support.

\section{REFERENCES}

ALARCÓN J; AGUILA S. 2006. Lovastatin production by Pleurotus ostreatus: effects of the C:N ratio. Journal of Biosciences 61: 95-98.

BERNARDI E; DONINI LP; MINOTTO E; NASCIMENTO JS. 2009. Cultivo e características nutricionais de Pleurotus em substrato pasteurizado. Bragantia 68: 901-907.

CHERTMAN M. 2007. Secagem de papel produzido a partir do pseudocaule da bananeira. São Paulo: USP. 107p. (Tese mestrado).

CONTRERAS EP; SOKOLOV M; MEJÍA G; SÁNCHEZ JE. 2004. Soaking of substrate in alkaline water as a pretreatment for the cultivation of Pleurotus ostreatus. Journal of Horticultural Science \& Biotechnology 79: 234-240.

DIAS, ES. Mushroom cultivation in Brazil: challenges and potential for growth. 2010. Ciência e Agrotecnologia 34: 795-803.

DIAS ES; KOSHIKUMO EMS; SCHWAN 
RS; SILVA R. 2003. Cultivo do cogumelo Pleurotus sajor-caju em diferentes resíduos agrícolas. Ciência e Agrotecnologia 27: 1363-1369.

DONINI LP; BERNARDI E; NASCIMENTO JS. 2006. Colonização do substrato capim-elefante suplementado com farelos por Pleurotus ostreatus. Revista de Biologia e Ciências da Terra 6: 185-193.

DONINI LP; BERNARDI E; MINOTTO E; NASCIMENTO JS. 2009. Cultivation of shimeji on elephant grass substrate supplemented with different kinds of bran. Scientia Agraria 10: 67-74.

GUNDE-CIMERMAN N; CIMERMAN A. 1995. Pleurotus fruiting bodies contain the inhibitor of 3-hydroxy-3-methylglutaryl-coenzyme A reductase-lovastatin. Experimental Mycology 19: 1-6.

GONÇALVES CCM; PAIVA PCA; DIAS ES; SIQUEIRA FG; HENRIQUE F. 2010 Evaluation of the cultivation of Pleurotus sajor-caju (Fries) Sing. cotton textile mill waste for mushroom production and animal feeding. Ciência e Agrotecnologia 34: 220 225 .

JEDINAK A; SLIVA D. 2008. Pleurotus ostreatus inhibits proliferation of human breast and colon cancer cells through p53-dependent as well as p53-independent pathway. International Journal of Oncology 33: 1307-1313.

KEREM Z; HADAR Y. 1995. Effect of manganese on preferential degradation of lignin by Pleurotus ostreatus during solidstate fermentation. Applied Environmental Microbiology 61: 3057-3062.

MANDEEL QA; AL-LAITH AA; MOHAMED SA. 2005. Cultivation of oyster fungus (Pleurotus spp) on various lignocellulosic wastes. World Journal of Microbiology \&
Biotechnology 21: 601-607.

MAZIERO R; BONONI VL; CAPELARI M. 1992. Cultivo e produtividade de Pleurotus ostreatus var. Florida em Mogi das Cruzes, Brasil. Hoehnea 19: 1-7.

MISLEVY P. 1985. Forages for grazing systems in warm climates. In: McDOWELL LR. Nutrition of grazing ruminants in warm climates. New York: Academic Press. p. 73-102.

MODA EM; HORII J; SPOTO MHF. 2005. Edible fungus Pleurotus sajor-caju production on washed and supplemented sugarcane bagasse. Scientia Agricola 62: 127-132.

MONTEIRO FA. 1986. Sulfur fertilization and nutrient distribution in a Florida spodosol profile under white clover-Pensacola Bahia grass. Gainesville: University of Florida. 182p. (Ph.D. thesis).

OBODAI M; CLELAND-OKINE J; VOWOTOR KA. 2003. Comparative study on the growth and yield of Pleurotus ostreatus fungus on different lignocellulosic by-products. Journal Industry Microbiology \& Biotechnology 30: 146-149.

OLIVEIRA AMG; AQUINO AM; CASTRONETO MT. 2005. Compostagem caseira de lixo orgânico doméstico. Embrapa Mandioca e Fruticultura Tropical, Circular Técnica 76:1-6.

PRAMANIK M; MONDAL S; CHAKRABORTY I; ROUT D; ISLAM SS. 2005. Structural investigation of a polysaccharide (Fr. II) isolated from the aqueous extract of an edible mushroom, Pleurotus sajor-caju. Carbohydrate Research 340: 629-636.

ROYSE DJ. 2003. Cultivation of oyster mushroom. College of Agricultural Sciences/The Pennsylvania State University Park University: Agricultural Research and Cooperative Extension. CAT UL207
3m1/03ACG4562. http://pubs.cas.psu.edu/ FreePubs/pdfs/UL207.pdf.

SHARMA HSS. 1995. Thermogravimetric analysis of fungus (Agaricus bisporus) compost for fibre components. In: ELLIOT T. (ed) Proceedings of the $14^{\text {th }}$ International Congress on the Science and Cultivation of Edible Fungi. Balkema, Rotterdam: p. 267-273.

SILVA DJ; QUEIROZ AC. 2002. Análise de alimentos: métodos químicos e biológicos $-3^{a}$ ed. Viçosa: UFV. 235p.

SILVA EG; DIAS ES; SIQUEIRA FG; SCHWAN RF. 2007. Análise química de corpos de frutificação de Pleurotus sajor-caju cultivado em diferentes concentrações de nitrogênio. Ciência e Tecnologia de Alimentos 27: 72-75.

SOFFNER MLAP. 2001. Produção de polpa celulósica a partir de engaço de bananeira. Piracicaba: ESALQ/USP 67p. Piracicaba: ESALQ/USP. 67p. (Tese mestrado).

STURION GL. 1994. Utilização da folha de bananeira como substrato para o cultivo de cogumelos comestiveis (Pleurotus spp.). Piracicaba: ESALQ/USP. 56p. (Tese mestrado).

THOMAS GV; PRABHU SR; REENY MZ; BOPAIAH, BM. 1998. Evaluation on lignocellulosic biomass from coconut palm as substrate for cultivation of Pleurotus sajor-caju (Fr.) Singer. World Journal of Microbiology \& Biotechnology 14: 879-882.

VAN SOEST PJ. 1994. Nutritional ecology of the ruminant. 2.ed. Ithaca: Cornell University Press. 476p.

ZADRAZIL F; BRUNNERT H. 1980. Influence of ammonium nitrate on the growth and decomposition of higher fungi. Applied Microbiology and Biotechnology 9: 37-44. 